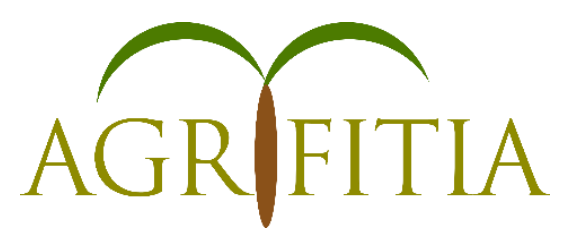

Journal Agrifitia. Vol. 1, No. 2, September 2021

Journal home page: https://jurnal.instiperjogja.ac.id/index.php/AFT

\title{
ANALISIS PERAN TENAGA KERJA WANITA DALAM MENINGKATKAN EKONOMI KELUARGA DI PT GERSINDO MINANG PLANTATION
}

\author{
Maullidiah Ayu Rahmita ${ }^{1}$, Istiti Purwandari ${ }^{1}$, Christina Wahyu Ary Dewi ${ }^{1}$ \\ ${ }^{1}$ Jurusan Ekonomi Pertanian, Fakultas Pertanian, INSTIPER Yogyakarta \\ Jl. Nangka II, Maguwoharjo (Ringroad Utara), Yogyakarta 55282, Indonesia
}

\begin{abstract}
Women have many roles in the household, including social roles as well as economic roles. This study aims to :1) determine how big the role of female workers in improving the family economy at PT Gersindo Minang Plantation, 2) To determine the factors that influence the role of women in improving the family economy at PT Gersindo Minang Plantation. The method used in this study is descriptive, the basic method for sampling is the simple random sampling method with a random sampling technique without regard to the existing strata in the population. The ruslts of this study is that the income of female workers has a significant effect on the family's economy, while the factors that influence the role of women in improving the family economy are age and husband's status.
\end{abstract}

Keywords : roles, women's labor, family economics 


\section{PENDAHULUAN}

Wanita memiliki peran penting bagi keluarga, karena wanita merupakan istri sekaligus ibu dalam rumah tangga. Keadaan ekonomi yang semakin tidak menentu, harga kebutuhan pokok yang semakin meningkat dan pendapatan keluarga yang cendrung tidak meningkat akan berakibat pada terganggunya stabilitas perekonomian keluarga. Kondisi tersebut yang mendorong wanita untuk bekerja. Perempuan hanya pekerja sampingan yang membantu suami dan memberikan tambahan kontribusi ekonomi bagi rumah tangganya. Pendapatan yang mereka dapatkan pada hari itu langsung mereka kontribusikan ke rumah tangganya untuk memenuhi kebutuhan pokok dari rumah tangganya (Samosir, 2017).

Wanita yang bekerja harus bisa membagi waktu antara waktu bekerja dengan kegiatan sebagai ibu rumah tangga. Wanita bekerja dipengaruhi beberapa faktor, antara lain faktor sosial dan faktor ekonomi. Faktor ekonomi merupakan salah satu faktor yang dapat mempengaruhi keputusan perempuan yang sudah menikah untuk bekerja karena kurangnya pendapatan dari suami mereka, sedangkan faktor sosial juga merupakan faktor penting yang berpengaruh terhadap keputusan wanita bekerja, apa yang boleh dilakukan dan apa yang tidak boleh dilakukan. Hal tersebut berkaitan dengan pandangan masyarakat atau sosial bahwa wanita bekerja di luar rumah menjadi hal yang belum biasa dalam pandangan masyarakat, karena yang seharusnya bekerja adalah kaum laki-laki (Manalu, 2014).

Peran perempuan bekerja di perkebunan juga sama halnya dengan peran perempuan yang bekerja di luar dari perkebunan tujuannya hanya untuk memenuhi kebutuhan ekonomi mereka dan juga menambah pendapatan dari suami untuk keluarganya. Pekerjaan untuk wanita di perkebunan sebagian besar sebagai BHL yang bekerja di bagian perawatan dan sedikit di bagian panen.

Penelitian ini bertujuan untuk mengetahui seberapa besar peran wanita dalam meningkatkan ekonomi keluarga dan juga untuk mengetahui faktor-faktor yang mempengaruhi peran wanita dalam meningkatkan ekonomi keluarga.

\section{METODOLOGI}

Metode yang digunakan dalam penelitian ini adalah metode Simple Random Sampling yaitu teknik pengambilan sampel dari anggota atau populasi yang dilakukan secara acak tanpa memperhatikan strata yang ada dalam populasi tenaga kerja wanita yang berada di perkebunan kelapa sawit tersebut dengan jumlah 30 orang tenaga kerja.

Penelitian dilakukan dengan pendekatan deskriptif dan juga pendekatan kuantitatif yang di gunakan untuk mengetahui seberapa besar peran tenaga kerja wanita dan juga apa saja faktor-faktor yang berpengaruh terhadap peran wanita dalam meningkatkan ekonomi keluarganya. Untuk analisis dibentuk model dengan persamaan sebagai berikut : 


\section{$Y=\alpha+\beta 1 X 1+\beta 2 X 2+\beta 3 X 3+\beta 4 X 4+d 1 D 1+d 2 D 2+e$}

Di mana :

$\mathrm{Y}=$ Peran wanita dalam meningkatkan ekonomi ( dalam satuannya \%)

$\alpha=$ Konstanta / Intercept $\beta=$ Koefisien Regresi

$\mathrm{e}=$ Term Of Error $\mathrm{X} 1=$ Usia (Tahun) $\mathrm{X} 2=$ Pendidikan

X3= Lama bekerja (Tahun)

X4 = Jumlah Tanggungan keluarga (orang)

D1 =Status suami

D2 = Motivasi

\section{HASIL DAN PEMBAHASAN}

\section{A. Identitas Tenaga Kerja Wanita}

1. Usia Tenaga Kerja Wanita

Usia merupakan karakteristik seseorang yang mencerminkan kemampuan dan kondisi seseorang secara fisik. Tenaga kerja wanita di PT Gersindo Minang Plantation, tidak terbatas pada usia tertentu. Variasi usia yang bekerja sebagai tenaga kerja paling muda adalah 27 tahun, sedangkan yang paling tua 51 tahun. Dari hasil penelitian diperoleh jumlah tenaga kerja wanita yang paling banyak adalah usia 31 - 40 tahun sebanyak $50 \%$ dan yang paling sedikit yaitu usia 17 - 30 tahun sebanyak 13,33\%. Dengan demikian dapat dikatakan bahwa pada rentang usia 31- 40 tahun merupakan usia produktif. Selain itu, pada rentang usia tersebut mereka memiliki pengeluaran yang sangat besar untuk memenuhi kebutuhan hidup keluarga, sehingga para Wanita memutuskan untuk bekerja. Sedangkan usia yang lebih muda lebih banyak memilih bersekolah atau memilih bekerja di luar dari perkebunan dengan alasan gaji di luar lebih besar dari pada gaji yang bekerja di perkebunan.

\section{Pendidikan Tenaga Kerja Wanita}

Pendidikan merupakan tingkatan pendidikan terakhir yang diselesaikan oleh pekerja wanita di PT Gersindo Minang Plantation, semakin tinggi tingkat pendidikan seseorang maka semakin banyak pula pengetahuan yang dimilikinya. Pendidikan dapat menentukan seseorang bekerja sesuai dengan kemampuan yang dimilikinya dan juga pendidikan yang didapat oleh seseorang bisa meningkatkan cara berfikir seseorang karena dengan pendidikan yang tinggi maka pola pikir seseorang diharapkan lebih bijak dalam menyikapi suatu pekerjaan maupun masalah yang ada di lingkungan pekerjaan.

Dari hasil penelitian yang dilakukan tingkat pendidikan responden dengan persentase tertinggi sebesar $46,67 \%$ adalah SD dan yang terendah sebesar $13,33 \%$ adalah SMA. Sehingga banyak yang dijumpai tenaga kerja wanita yang pendidikan rendah mereka hanya bekerja di luar ruangan atau dil apangan berbeda dengan wanita yang berpendidikan tinggi 
mereka akan bekerja di dalam ruangan dengan pola pikir yang baik dan juga lebih meningkatkan kualitas dan ekonomi mereka.

\section{Jumlah Tanggungan Keluarga Tenaga Kerja Wanita}

Jumlah tanggungan keluarga adalah jumlah anggota keluarga yang di tanggung oleh responden dalam rumah tangganya. Anggota keluarga yang menjadi tanggungan dalam suatu rumah tangga meliputi suami, istri, anak dan orang lain yang tinggal dengan responden menjadi tanggungan responden tersebut.

Dari hasil penelitian menunjukkan bahwa jumlah tanggungan keluarga wanita pekerja kebun dengan persentase tertinggi sebesar 53,34\% yaitu berjumlah 3 sampai 4 orang. Sedangkan dengan jumlah tanggungan 1 sampai 2 orang dengan persentase 23,33 \%. Hal tersebut menunjukkan bahwa semakin banyaknya jumlah tanggungan, semakin banyak juga jumlah pengeluarannya, sehingga mendorong wanita untuk bekerja.

\section{Jenis Pekerjaan Tenaga Kerja Wanita}

Jenis pekerjaan adalah suatu bentuk atau macam kegiatan yang dilakukan oleh tenaga kerja wanita di PT Gersindo Minang Plantation untuk meningkatkan pendapatan rumah tangga.

Dari hasil penelitian menunjukan bahwa $100 \%$ tenaga kerja wanita yang bekerja di PT Gersindo Minang Plantation ini merupakan pekerjaan pokok mereka dan bukan pekerjaan sampingan. Tenaga kerja wanita di PT Gersindo Minang Plantation ini sudah tidak ada lagi yang berstatus sebagai buruh harian lepas $(\mathrm{BHL})$, tetapi mereka berstatus sebagai karyawan tetap PT Gersindo Minang Plantation.

\section{Lama Kerja TenagaKerja Wanita}

Selain pendidikan yang sangat menentukan keberhasilan seseorang adalah lama masa kerja seseorang tenaga kerja, semakin lama masa kerjanya maka semakin terampil melakukan pekerjaan dan semakin sempurna pola berfikir serta sikap dalam bertindak. Oleh karena itu, lama masa kerja yang didapat seseorang akan meningkatkan kemampuan dalam melaksanakan pekerjaannya sehingga dapat juga meningkatkan pendapatannya.

Dari hasil penelitian diperoleh persentase tertinggi dalam lamanya bekerja yaitu 6 hingga 10 tahun sebesar 43,33 \%. Lama tenaga kerja wanita yang bekerja di PT Gersindo Minang Plantation yang paling rendah yaitu 2 tahun dan yang tertinggi 23 tahun dengan rata-rata keseluruhan lama bekerja tenaga kerja wanita yaitu $11,17 \%$. 


\section{B. Profil Pekerjaan Tenaga Kerja Wanita dan Keluarga di PT Gersindo Minang Plantation.}

\section{Posisi Pekerjaan Responden}

Hasil penelitian menunjukkan bahwa posisi wanita pekerja kebun di PT Gersindo Minang Plantation yang paling banyak adalah pekerja perawatan sebesar $83 \%$. Pekerjaan perawatan meliputi pemeliharaan kebun, pembibitan, penyemprotan, pemupukan, sedangkan $27 \%$ merupakan karyawan OB, pencucian karung dan krani.

\section{Jumlah Jam Kerja Tenaga Kerja Wanita}

Jumlah jam kerja merupakan waktu yang digunakan oleh tenaga kerja wanita untuk melakukan pekerjaan di PT Gersindo Minang Plantation. Dari penelitian diperoleh bahwa tenaga kerja wanita pekerja kebun di PT Gersindo Minang Plantation memiliki jumlah jam kerja 7 jam per harinya dan semua tenaga kerja wanita memiliki jumlah jam kerja yang sama.

\section{Pendapatan Tenaga Kerja Wanita Per Bulan}

Pendapatan perbulan yang dimaksud adalah pendapatan yang diterima oleh tenaga kerja wanita yang bekerja di PT Gersindo Minang Plantation setiap satu bulan sekali. Dari hasil penelitian menunjukkan bahwa sebagian besar tenaga kerja wanita di PT Gersindo Minang Plantation ini pendapatan perbulannya yaitu $R p 2.301 .000,00-R p 2.600 .000,00$ dengan persentase $98,33 \%$ dan tenaga kerja wanita yang mendapatkan pendapatan terendah Rp 2.000.000,00 - Rp 2.301.000,00 perbulannya memilikin persentase 1,7\%. Upah terendah yakni $\mathrm{Rp} 2.000 .000,00$ dan upah tertinggi yaitu $\mathrm{Rp} 2.600 .000,00$ dengan ratarata upah yaitu Rp.2.467.300,00. Hal ini menunjukan bahwa pendapatan yang diperoleh dapat menambah penghasilan suami dan membantu perekonomian keluarga.

\section{Pendapatan Suami}

Pendapatan suami yang dimaksud adalah apakah pendapatan suami yang diperoleh perbulan dapat mencukupi ekonomi keluarga atau tidak, sehingga wanita memutuskan untuk bekerja sebagai karyawan di PT Gersindo Minang Plantation untuk memenuhi kebutuhan keluarganya. Dari hasil penelitian dapat dilihat bahwa sebagian besar pendapatan dari suami berkisar antara Rp 2.500.000,00 - Rp 3.500.000,00 dengan persentase 73,33\%, dan yang bekerja dengan pendapatan antara Rp.1.000.000,00 - Rp 2.000.000,00 persentasenya 27\%. Karena pendapatan suami yang rendah sehingga tidak dapat mencukupi kebutuhan keluarga, maka istri memutuskan untuk bekerja membantu perekonomian keluarganya.

\section{Pendapatan Anak}

Pendapatan anak yang dimaksud adalah apakah pendapatan anak yang diperoleh anak dari tenaga kerja Wanita perbulan dapat membantu mencukupi ekonomi keluarga atau tidak. Di PT Gersindo Minang Plantation ini hanya ada beberapa anak dari tenaga kerja wanita yang bekerja. 
Hasil penelitian menunjukkan bahwa anak dari tenaga kerja wanita di PT Gersindo Minang Plantation yang bekerja serta dapat membantu ekonomi keluarganya ada 9 orang. Dengan pendapatan antara Rp1.000.000,00 - Rp 2.000.000,00 ada 7 orang, dengan pendapatan antara Rp 2.500.000,00 -Rp 3.000.000,00, ada 1 orang, dan yang pendapatannya antara Rp 3.500.000,00 - Rp 4.000.000,00 juga ada 1 orang.

\section{Rata- rata pendapatan Istri, Suami, Anak}

Dari penelitian yang telah dilakukan di PT Gersindo Minang Plantation diperoleh bahwa jumlah rata-rata pendapatan dari istri, suami dan anak yang diterima perbulannya untuk memenuhi ekonomi keluarga yaitu rata-rata pendapatan istri perorangnya sebesar $\mathrm{Rp}$ 2.467,300,00, suami sebesar Rp 2.317.500,00 dan anak sebesar Rp 533,333,00.. Wanita berperan $46 \%$ dalam pendapatan keluarga, sedangkan suami hanya berperan $43 \%$.

\section{Peran Tenaga Kerja Wanita Dalam Meningkatkan Ekonomi Keluarga di PT Gersindo Minang Plantation.}

Peran Tenaga kerja Wanita dalam meningkatkan ekonomi keluarga yaitu memberikan kontribusi pendapatan. Dengan bekerja wanita berharap akan ada perubahan bagi kehidupan rumah tangganya, sehingga sebagian wanita memilih bekerja agar dapat berkontribusi dalam ekonomi keluarganya (Sajogyo,1984).

\section{Pendapatan Tenaga Kerja Wanita Berdasarkan Usia}

Usia sangat berpengaruh terhadap kemampuan fisik tenaga kerja dalam memproduksi barang dan jasa. Usia tenaga kerja wanita antara 27 - 51 tahun masih sangat baik dan produktif saat melakukan pekerjaan, namun untuk tenaga kerja wanita dengan usia di atas 51 tahun jam kerjanya akan sedikit menurun karena usia tenaga kerja wanita tersebut sudah tidak produktif untuk melakukan pekerjaan di kebun.

Dari hasil penelitian dapat diketahui distribusi pendapatan tenaga kerja wanita berdasarkan usia. Untuk usia 27 - 34 tahun berjumlah 7 orang tenaga kerja wanita dengan rata-rata pendapatan yang mereka terima sebesar $\mathrm{Rp} 2.487 .142,00$, sedangkan untuk usia 35 - 42 tahun berjumlah 14 orang tenaga kerja wanita dengan rata-rata pendapatan sebesar Rp 2.439.428,00 dan untuk usia 43 - 51 tahun berjumlah 9 orang tenaga kerja wanita dengan rata-rata pendapatan sebesar $\mathrm{Rp} 2.495 .222,00$.

\section{Pendapatan Tenaga Kerja Wanita Berdasarkan Pendidikan}

Pendidikan akan memberikan kemampuan seseorang untuk berfikir rasional dan objektif dalam menghadapi suatu masalah. Semakin tinggi pendidikan seseorang maka semakin besar juga peluang untuk bekarja di suatu bidang pekerjaan oleh sebab itu pendidikan sangatlah penting bagi tenaga kerja wanita karena pendapatan dan posisi pekerjaan serta kemampuan mereka akan dilihat dari pendidikannya (Simanjuntak, 2001). 
Dari hasil penelitian pendidikan tenaga kerja wanita yang terendah adalah SD yaitu sebanyak 14 orang dengan rata-rata pendapatan $\mathrm{Rp} 2.485 .000,00$, untuk tenaga kerja wanita dengan pendidikan SMP sebayak 12 orang, dengan rata-rata pendapatan Rp2.479.000,00, sedangkan pendidikan teratas yaitu SMA sebanyak 4 orang dengan rata-rata pendapatan Rp 2.375.000,00.

\section{Pendapatan Tenaga Kerja Wanita Berdasarkan Lama Bekerja}

Jangka waktu tenaga kerja wanita dalam bekerja di PT Gersindo Minang Plantation mulai dari pertama masuk bekerja hingga hari ini dapat dihitung berapa lama tenaga kerja wanita tersebut bekerja. Dari hasil penelitian dapat dilihat bahwa tenaga kerja wanita rata - rata pendapatannya berdasarkan lama bekerjanya yaitu tenaga kerja wanita yang bekerja 2 - 8 tahun berjumlah 15 orang dengan rata-rata pendapatan sebesar $\mathrm{Rp}$ 2.480.000,00, tenaga kerja wanita yang bekerja 9 - 15 tahun berjumlah 6 orang dengan ratarata pendapatan sebesar $\mathrm{Rp} 2.480 .000,00$, sedangkan tenaga kerja wanita yang bekerja selama 16 - 23 tahun ada 9 orang dengan rata-rata pendapatan sebesar $\mathrm{Rp} 2.436 .000,00$.

\section{Pendapatan Berdasarkan Jumlah Tanggungan Keluarga.}

Jumlah tanggungan keluarga adalah jumlah anggota keluarga karyawan wanita pekerja kebun di PT Gersindo Minang Plantation yang menjadi tanggungan tenaga kerja wanita dalam satu rumah. Rata - rata pendapatan berdasarkan jumlah tanggungan keluarganya. Dari hasil penelitian dapat dilihat bahwa tanggungan keluarga dari tenaga kerja wanita yang memiliki jumlah tanggungan paling sedikit ada 7 orang yaitu 1 - 2 orang dengan rata - rata pendapatan sebesar Rp 2.482.000,00, tanggungan 3 - 4 ada 16 orang dengan rata - rata pendapatan sebesar Rp 2.480.000,00, sedangkan tanggungan 5 - 6 ada 7 orang dengan rata - rata pendapatan sebesar Rp 2.494.000,00.

\section{Status Pekerjaan Suami}

Status suami yang dimaksud adalah pekerjaan suami dalam menafkahi keluaranya. Status suami dalam bekerja dapat dilihat dari pekerjaannya di dalam atau di luar kebun sebagai pencari nafkah untuk memenuhi kebutuhan hidup keluarganya. Di PT Gersindo Minang Plantation ada beberapa suami yang bekerja di luar perkebunan.

Dari hasil penelitian diketahui bahwa suami yang bekerja di kebun ada 25 orang dengan rata-rata pendapatan sebesar Rp 2.509.000,00, sedangkan suami yang bekerja serabutan ada 5 orang dengan rata-rata pendapatan sebesar Rp1.360.000,00. Serabutan yang dimaksud di sini yaitu suami yang pekerjaannya tidak menentu akan tetapi dia menghasilkan dan mendapatkan pendapatan untuk keluarganya. 


\section{Motivasi Tenaga Kerja Wanita}

Dari hasil penelitian diperoleh bahwa motivasi responden untuk bekerja berasal dari dalam diri wanita pekerja kebun di PT Gersindo Minang Plantation untuk meningkatkan ekonomi dan juga pendapatan keluarganya. Motivasi tersebut jelas mempengaruhi tenaga kerja wanita untuk semakin bersemangat dalam bekerja.

\section{E. Hasil Uji}

Hasil uji besaran peran tenaga kerja wanita dalam meningkatkan ekonomi keluarga Di PT Gersindo Minang Plantation.

Tabel t Besar Peran Tenaga Kerja Wanita

\begin{tabular}{|l|r|r|r|r|}
\multicolumn{4}{|c}{ Model Summary } \\
\hline Model & $\mathrm{R}$ & R Square & $\begin{array}{c}\text { Adjusted } \\
\text { R Square }\end{array}$ & $\begin{array}{c}\text { Std. Error of } \\
\text { the Estimate }\end{array}$ \\
\hline 1 &, $218^{\mathrm{a}}$ &, 047 &, 013 & 1056525,06 \\
\hline
\end{tabular}

a. Predictors: (Constant), pendapatan_wanita

Dari uji regresi di atas dapat disimpulkan bahwa pendapatan tenaga kerja wanita yang bekerja di PT Gersindo Minang Plantation berpengaruh nyata terhadap ekonomi keluarganya karena memiliki nilai signifikasi yaitu $5 \%$.

Hasil uji faktor - faktor yang mempengaruhi peran wanita dalam meningkatkan ekonomi keluarga di PT Gersindo Minang Plantation

Tabel uji parsial $t$

\begin{tabular}{|c|c|c|c|c|c|c|c|c|}
\hline \multicolumn{9}{|c|}{ Coefficients $^{a}$} \\
\hline \multirow{2}{*}{\multicolumn{2}{|c|}{ Model }} & \multicolumn{2}{|c|}{$\begin{array}{l}\text { Unstandardized } \\
\text { Coeff icients }\end{array}$} & \multirow{2}{*}{$\begin{array}{c}\text { Standardized } \\
\text { Coeff icients }\end{array}$} & \multirow[b]{2}{*}{$t$} & \multirow[b]{2}{*}{ Sig. } & \multicolumn{2}{|c|}{ Collinearity Statistics } \\
\hline & & $B$ & Std. Error & & & & Tolerance & VIF \\
\hline \multirow[t]{7}{*}{1} & (Constant) & 9,224 & 1,564 & & 5,900 & 000 & & \\
\hline & $\mathrm{X} 1$ &,- 070 & ,034 &,- 438 & $-2,067$ & ,050 & ,499 & 2,002 \\
\hline & $\mathrm{X} 2$ & ,036 & 081 & 073 & 444 & 661 & 824 & 1,214 \\
\hline & X3 &,- 027 & ,029 &,- 189 &,- 928 & ,363 & ,539 & 1,855 \\
\hline & $\mathrm{X} 4$ & -127 & 141 &,- 142 &,- 903 & ,376 & ,906 & 1,103 \\
\hline & D1 & $-1,396$ & ,456 &,- 508 & $-3,060$ & ,006 & 813 & 1,231 \\
\hline & D2 &,- 521 & ,393 &,- 225 & $-1,327$ & 198 & ,778 & 1,285 \\
\hline
\end{tabular}

a. Dependent Variable: $Y$

Dari hasil analisis uji t status suami dan usia tenaga kerja wanita berpengaruh nyata terhadap peran tenaga kerja wanita dalam ekonomi keluarga. Bahwa suami yang bekerja diperkebunan memiliki rata-rata pendapatan lebih besar dari pada pendapatan tenaga kerja wanita (istri) sedangkan suami yang bekerja serabutan pendapatannya lebih kecil dari pada pendapatan tenaga kerja wanita (istri) di PTGersindo Minang Plantation karena pendapatan dari wanitanya lebih tinggi. Akan tetapi variabel pendidikan, lama bekerja, jumlah tanggungan keluarga,dan motivasi tidak berpengaruh terhadap peran tenaga kerja wanita. 
Tabel Uji F

Tabel Model Summary

\begin{tabular}{|l|r|r|r|r|r|}
\multicolumn{7}{|c|}{ Model Summary $^{\text {b }}$} \\
\hline Model & \multicolumn{1}{|c|}{$R$} & R Square & $\begin{array}{c}\text { Adjusted } \\
\text { R Square }\end{array}$ & $\begin{array}{r}\text { Std. Error of } \\
\text { the Estimate }\end{array}$ & $\begin{array}{c}\text { Durbin- } \\
\text { Watson }\end{array}$ \\
\hline 1 &, $696^{\mathrm{a}}$ &, 485 &, 350 &, 83952 & 1,637 \\
\hline
\end{tabular}

a. Predictors: (Constant), D2, X4, X3, X2, D1, X1

b. Dependent Variable: $Y$

Dari hasil uji F dapat diketahui bahwa usia dari tenaga kerja wanita dan status suami berpengaruh nyata terhadap peran tenaga kerja wanita dalam meningkatkan ekonomi keluarga di PT Gersindo Minang Plantation, sedangkan pendidikan, lama bekerja, jumlah tanggungan keluarga dan motivasi tidak berpengaruh nyata terhadap peran tenaga kerja wanita dalam meningkatkan ekonomi keluarga di PT Gersindo Minang Plantation.

Dan dari tabel uji $F$ di atas nilai regresinya $R^{2}$ yaitu 0,485 dan nilai yang signifikansi sebesar $5 \%$ artinya dari faktor-faktor yang mempengaruhi peran tenaga kerja wanita di PT Gersindo Minang Plantation ini berpengaruh nyata sebesar $48 \%$ terhadap peran tenaga kerja wanita di PT Gersindo Minang Plantation

\section{KESIMPULAN}

Berdasarkan hasil penelitian mengenai peran tenaga kerja wanita dalam meningkatkan ekonomi keluarga di PT Gersindo Minang Plantation dapat disimpulkan bahwa :

1. Pendapatan tenaga kerja wanita berpengaruh nyata terhadap peningkatan ekonomi keluarga.

2. Faktor yang mempengaruhi peran wanita dalam peningkatan ekonomi keluarga adalah umur dan status suami.

\section{DAFTAR PUSTAKA}

Manalu, Afriyame dkk. 2014. "Faktor-Faktor Yang Mempengaruhi Wanita Bekerja Sebagai Buruh Harian Lepas di PT. Inti Indosawit Subur Muara Bulian Kecamatan Maro Sebo Ilir Kabupaten Batang Hari. Jambi: Universitas Jambi.

Samosir, Rebeca. 2017. "Perempuan Pekerja Kebun Sawit di Desa Bukit AgungSiak". Riau: Fakultas IImu Sosial dan Politik.

Sajogyo, Pudjiwati. 1984. "Peranan Wanita Dalam Perkembangan Ekonomi”. Jakarta: Yayasan Obor Indonesia.

Simanjuntak, P. 2001. “Pengantar Ekonomi Sumber Daya Manusia”. Jakarta: LP3ES.

Tuwu, Darmin. 2018. "Peran Pekerja Perempuan Dalam Memenuhi Ekonomi Keluarga : Dari Peran Domestik Menuju Sektor Publik" Jurnal Hasil-hasil Penelitian, Fakultas IImu Sosial dan Politik Universitas Haluoleo, Kendari, Volume 13 Nomor 1 (Mei, 2018) : 63 $-76$. 